\title{
Sertoli Cell Nodule with Histomorphological and Immunohistochemical Features and its Differential Diagnosis: A Case Report
}

\author{
Histomorfolojik ve İmmunhistokimyasal Özellikleri ile Sertoli Hücreli Nodül \\ ve Ayırıc1 Tanıs1: Bir Olgu Sunumu
}

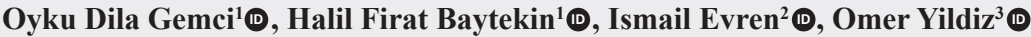

${ }^{1}$ Department of Pathology, University of Health Sciences, Dr. Sadi Konuk Training and Research Hospital, Istanbul, Turkey

${ }^{2}$ Department of Urology, University of Health Sciences, Dr. Sadi Konuk Training and Research Hospital, Istanbul, Turkey

${ }^{3}$ Department of Radiology, University of Health Sciences, Dr. Sadi Konuk Training and Research Hospital, Istanbul, Turkey

Cite as: Dila Gemci O, Baytekin HF, Evren I, Yildiz O. Sertoli cell nodule with histomorphological and immunohistochemical features and its differential diagnosis: a case report. Grand J Urol 2022;2(1):33-7.

Submission date: 26 March 2021

Acceptance date: 25 August 2021

Online First: 19 September 2021

Publication date: 20 January 2022

Corresponding Author: Oyku Dila Gemci / University of Health Sciences, Dr. Sadi Konuk Training and Research Hospital, Department of Pathology, Istanbul, Turkey / oykudilagemci@gmail.com / ORCID ID: 0000-0002-6558-7258

\begin{abstract}
Non-germ cell testicular tumors are rarely seen. Sex-cord stromal tumors, which make up the majority of testicular tumors other than germ cell tumors, share common immunohistochemical and histomorphological features. Our aim in presenting this case is to define the Sertoli cell nodule (SCN), which is one of the relatively rare primary testicular pathologies that can be detected in half of adult undescended testes, with its histomorphological and immunohistochemical features, and to make its differential diagnosis.
\end{abstract}

Keywords: Sertoli cell nodule, testicular dysgenesis syndrome, testicular nodule, testicular pathology, testicular tumor

Öz

Germ hücreli dişı testis tümörleri nadir görülürler. Germ hücreli tümörler dişında kalan testis tümörlerinin çoğunluğunu oluşturan seks-kord stromal tümörler ortak immunhistokimyasal ve histomorfolojik özellikler paylaşırlar. Bu olgunun sunulmasındaki hedefimiz, erişkin inmemiş testislerin yarısında saptanabilen, görece olarak nadir primer testiküler patolojilerden biri olan Sertoli hücreli nodülün (SCN), histomorfolojik ve immunhistokimyasal özellikleri ile tanımlanması ve ayırıcı tanısının yapılmasıdır.

Anahtar kelimeler: Sertoli hücreli nodül, testiküler disgenezi sendromu, testiküler nodül, testiküler patoloji, testis tümörü 


\section{Introduction}

Tumors of the testicles other than germ cell neoplasms are extremely rare and the majority of testicular neoplasms in this group are sex cord stromal tumors. This class of tumors, mostly with a benign course, are more common in childhood. It constitutes $25 \%$, and $2-5 \%$ of all testicular neoplasms in prepubertal ages and in adults, respectively [1].

Leydig cell tumors are the most common sex cord stromal tumors, followed by Sertoli cell tumors, granulosa cell tumors and myoid gonadal tumors in order of decreasing frequency [1]. Sertoli cell neoplasia group, which is the second most common testicular tumors after Leydig cell tumors among sex-cord stromal tumors, constitutes $1 \%$ of all testicular tumors [2].

Sertoli cell nodule (SCN) is defined as embryo-like nodular structures consisting of seminiferous tubules with a smaller diameter than the surrounding parenchyma. They can be detected as single or several separate nodules with diameters ranging from submillimeter up to one centimeter. They are rarely detected in normal testicles. The Sertoli cell nodule, which can be detected in half of the undescended testicles in adulthood, can be found in the normal testicular parenchyma in the peripheral part of germ cell tumors and in infertile patients.

\section{Case}

Clinical history; It was learned that a 31-year-old male patient admitted to the urology clinic with a complaint of right inguinal pain lasting for a month had limited range of motion due to intermittent pain and pain. Physical examination revealed that the right testicle was not in the scrotum, but in the inguinal canal. Examination of the genitourinary system was normal, except for the inguinal right testis. The patient's hemogram values and biochemical parameters were within normal limits. Oligoastenospermia was detected in the semen analysis of the patient.

In the scrotal color Doppler USG examination, the left testicle was of normal size, and structure, while the right testicle was in the inguinal canal and its size was smaller than the left testicle. Testicular contours were smooth, testicular parenchyma was homogeneously isoechoic, intratesticular vascularization was physiologic. Intratesticular space-occupying lesion was not detected. While the left epididymis was in natural appearance, the right epididymis was heterogeneously expanded compared to its normal size, and hypervascularization was detected. Right inguinal orchiectomy together with repair of right direct ingunal hernia detected during the operation was performed.

\section{Pathological Findings}

Macroscopic examination; A $5 \mathrm{~cm}$-long spermatic cord with a diameter of $2.5 \mathrm{~cm}$ at its widest part and an adjacent $4 \times 3 \times 2.5 \mathrm{~cm}$ testis in its normal structural appearance were observed. In the sections performed, solid millimetric nodules of off-white color with a smooth border with the surrounding testicular tissue, were found in several patchy areas in the normal-appearing testicular parenchyma.

Microscopic examination; In most areas, seminiferous tubules

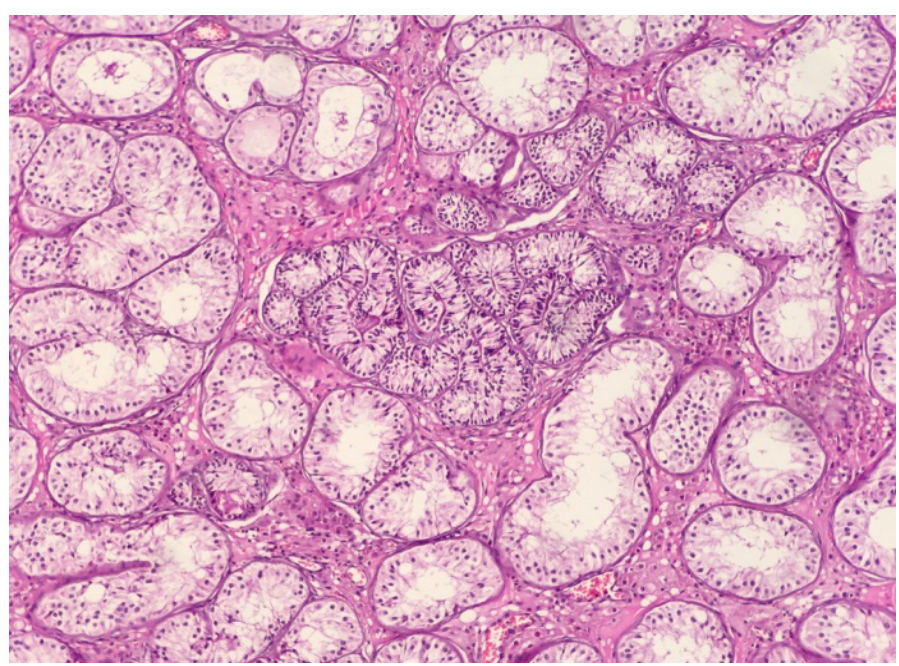

Figure 1. Submillimetric SCN consisting of large-diameter seminiferous tubules in the periphery and conglomerated infantile-looking tubules in the central area

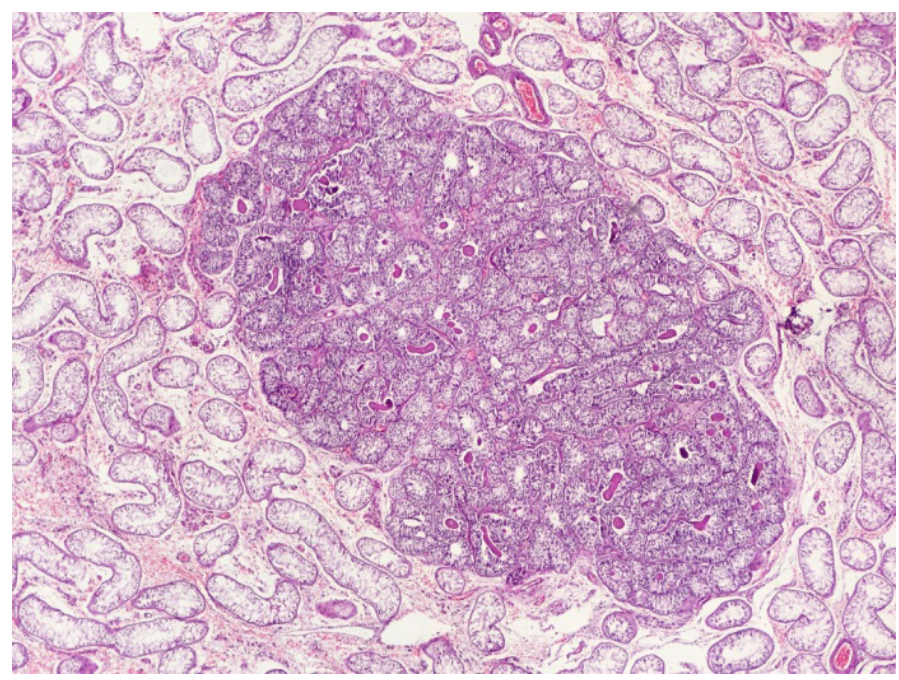

Figure 2. Fetal-looking tubules with narrow diameter and containing greater number of cells (x100 magnification), decreased amount of stroma when compared with the surrounding parenchyma

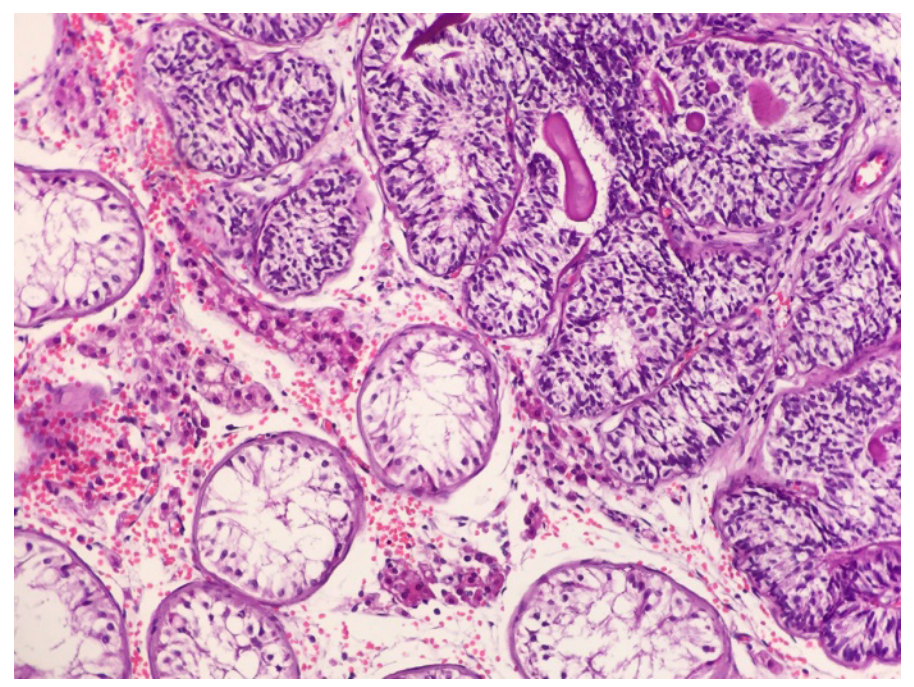

Figure 3. Stratified Sertoli cells, and intertubular Leydig cell clusters (x200 magnification) 
with open lumen, usually lined by a single layer of Sertoli cells with small round nuclei were observed (Figure 1). Although a small number of germ cells were observed in these seminiferous tubules, which can be demonstrated by SALL-4 immunohistochemical staining, it was observed that spermatogenesis stopped in the whole testicle.

In the testicular parenchyma, a few noncapsulated dispersed millimetric nodules separated from the environment by their smooth contours were observed. These nodules contained minimally wide interstitium, and adjacent seminiferous tubules denser than the surrounding parenchyma (Figure 2). Tubules in this nodular area were observed to be lined with only pseudostratified Sertoli cells with elongated hyperchromatic nuclei. Sertoli cell nuclei were hyperchromatic, elongated and contained one or two small peripheral nucleoli (Figure 3). Germ cells were detected in the conglomerated tubules in the nodular area by immunohistochemical methods at histomorphological level (Figure 4).

In immunohistochemical studies, Sertoli cells in nodular areas showed weaker reactivity with CD99, androgen receptor (AR) and inhibin than Sertoli cells in the surrounding tubules. In addition, while areas stained with desmin showed myoid cells around the seminiferous tubules outside the nodular areas, myoid cells were not detected in the nodular areas. The Ki-67 proliferation index was estimated as $1-2 \%$ in the densest area, higher than that of the surrounding parenchyma (Figure 5).

A few seminiferous tubules without stratified Sertoli cells, sharing similar features with non-nodular tubules surrounded by myoid cells, were detected in scarce number of peripheral tubules within the nodule (Figure 6). Although the nodular seminiferous tubules were lined with pseudostratified Sertoli cells, their fetal appearance was remarkable with their diameters narrower than those of the surrounding tubules. Basement membrane-like material densified in an amphophilic appearance in the tubule lumens was detected in all areas. With the histomorphological and immunohistochemical features described above, the case was reported as a Sertoli cell nodule.

\section{Discussion}

Sertoli cell nodule is defined as the presence of one or more separate foci in the testicular tissue, consisting of infantile-looking seminiferous tubules. Although the term Sertoli cell nodule was first reported in 1973, it was described as a "Pick adenoma" by Pick in 1905 and it was also reported as a lesion with similar features $[3,4]$. This lesion has also been termed in different reports with different names such as Sertoli cell hyperplasia, tubular dysgenesis or hypoplastic seminiferous tubule areas [5-7].

In the Sertoli cell nodule, each cluster of seminiferous tubules is observed as noncapsulated but well-defined nodules. Nodules can be single or multiple, millimetric or submillimetric. In a few published cases on macronodular Sertoli cell nodules, it has been reported that the nodules reached up to $1,7 \mathrm{~cm}$ in diameter [8]. Except for the rare presence of a palpable mass in large nodules at presentation, most of the time, any remarkable signs, and symptoms are not detected on clinical examination. Ultrasonographic findings may suggest a testicular tumor. Nodules can be single or multiple. Each nodule in the cross section can be

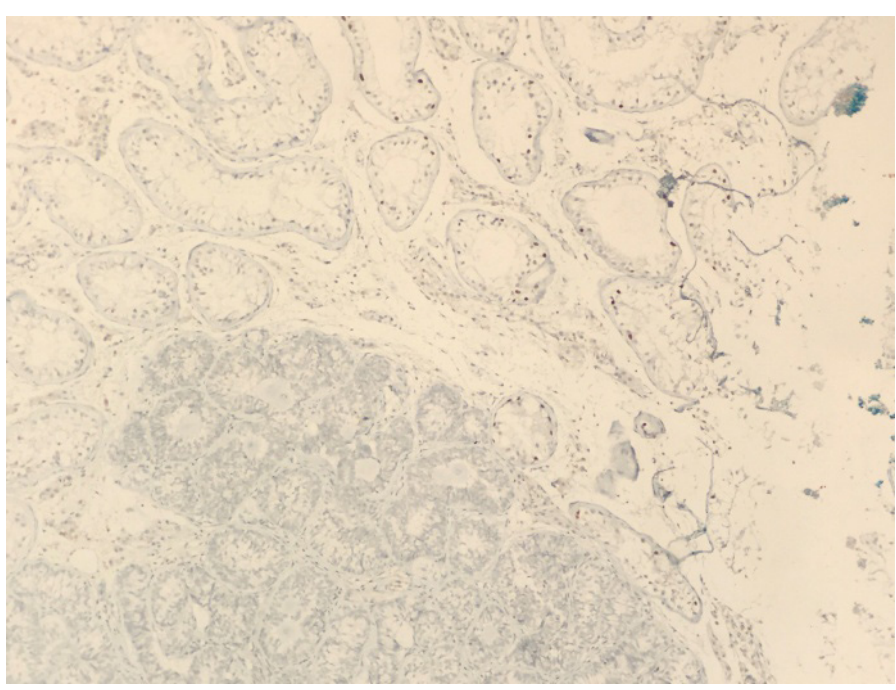

Figure 4. In immunohistochemical staining with SALL 4 while no germ cells are detected in SCN, a small number of germ cells are observed in the surrounding tubules
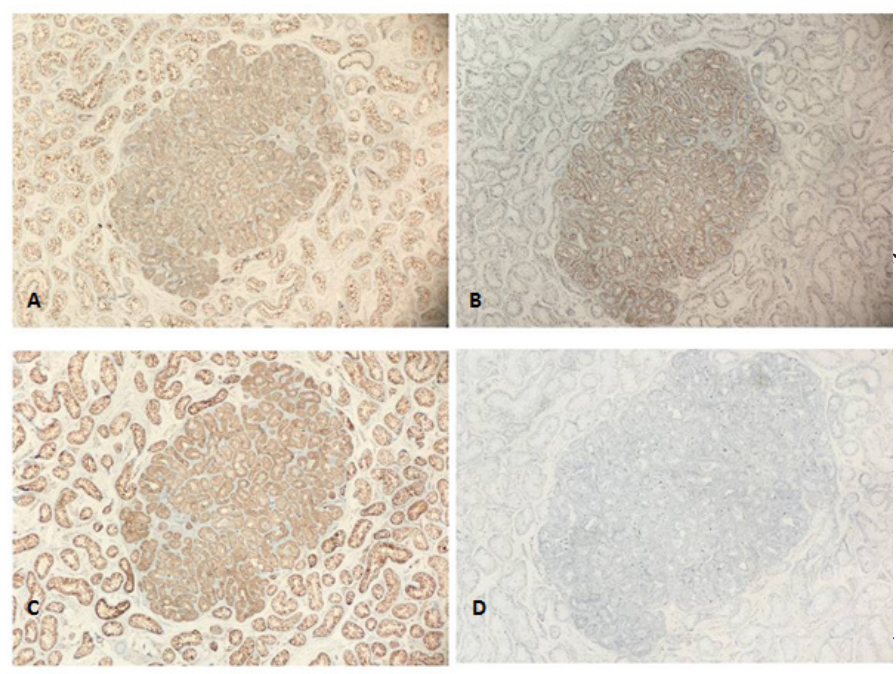

Figure 5. SCN immunohistochemical staining patterns; A- CD99, BAndrogen receptor, C- Inhibin, D- Ki-67

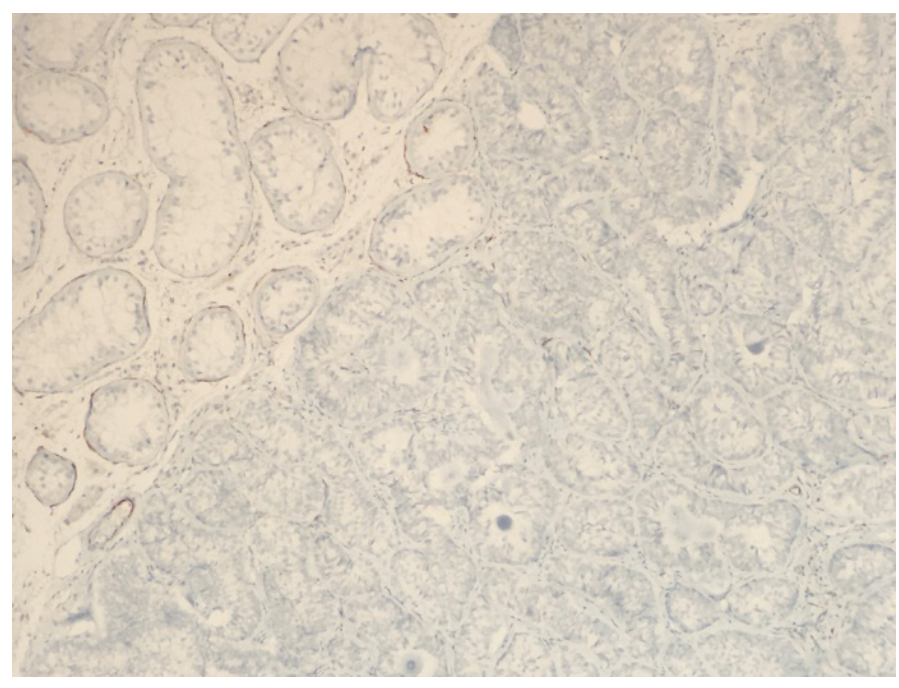

Figure 6. Parenchymal peritubular myoid cells were stained positively with desmin while myoid cells were not detected in the tubules forming the nodule 
differentiation, to clarify the microanatomy, or to show the presence and distribution of a particular cell type. Identification of the small numbers of germ cells was possible with SALL-4 immunohistochemistry. CD99, AR and inhibin were used for sex cord stromal differentiation, and desmin was used to demonstrate the presence of peritubular myoid cells. If the maturation of Sertoli cells cannot be determined histomorphologically, cytokeratin 8 and cytokeratin 18 expressions can be evaluated. These two types of keratin are used to identify immature Sertoli cells [10]. Differential diagnosis of Sertoli cell nodule include intratubular large cell hyalinizing Sertoli cell neoplasia, Sertoli cell adenoma, tubular hamartoma in androgen insensitivity syndrome (AIS), testicular areas containing focal Sertoli cell-only tubules, Sertoli cell tumor and gonodoblastoma.

In intratubular large cell hyalinizing Sertoli cell neoplasia (ITLCHSCN), multiple nodules are detected as in SCN, however, tubules do not anastomose in ITLCHSCN and are distinguished by their larger diameter. In addition, unlike the Sertoli cells observed in SCN, in ITLCHSCN the Sertoli cells with vesicular nuclei, central single nucleoli and eosinophilic cytoplasm, progress to the more advanced stages of maturation [11].

Though rarely, when SCN contains only a few germ cells, it is important to distinguish it from gonodoblastoma. Gonodoblastoma is almost always detected in gonadal dysgenesis or malformed testis, and it contains greater number of germ cells than SCN. Nodules consist of large clusters of Sertoli cells and germ cells surrounding the eosinophilic material rather than in the form of conglomerated tubules.

Macroscopically, Sertoli cell adenoma and tubular hamartoma in androgen insensitivity syndrome (AIS) are in the form of larger nodules, and the Sertoli cells lining the tubules are distinguished by having round nuclei rather than elongated ones.

In Sertoli cell- only tubules, nodular organization defined in SCN is not detected. They are found as tubules that consist entirely of Sertoli cells that do not tend to cluster. In the Sertoli cell nodule, the Sertoli cells and peritubular myoid cells, unlike the surrounding testicular parenchyma, do not respond to hormonal stimuli or respond irregularly and poorly. As a result, the prepubertal Sertoli cells lining the tubules and forming the lesion acquire a fetal-looking nodular structure consisting of conglomerated tubules. Different factors are thought to have an effect on the incomplete maturation of Sertoli cells in cryptorchidism. The main etiologic factors are exposure of the undescended testis to high temperature and congenital hormonal insensitivity [12].

It is important to distinguish SCN from Sertoli cell neoplasms. Sertoli cell nodules are mostly microscopic, rarely as single or multiple macroscopic nodules. Although mitosis was not detected in our case, it is thought-provoking that the $\mathrm{Ki}-67$ proliferation index is $1 \%$ higher than the environment, but today there is no evidence that these are precancerous lesions.

\section{Ethics Committee Approval: N / A.}

Informed Consent: An informed consent was obtained from the patient.

Publication: The results of the study were not published in full or in part in form of abstracts.
Peer-review: Externally and internally peer-reviewed.

Authorship Contributions: Any contribution was not made by any individual not listed as an author. Concept - O.D.G.; Design - O.D.G.; Supervision - O.D.G.; Resources - H.F.B.; Materials O.D.G., I.E.; Data Collection and/or Processing - O.Y.; Analysis and/or Interpretation - O.D.G, I.E.; Literature Search - O.D.G., H.F.B.; Writing - O.D.G., H.F.B., I.E.; Critical Review - O.D.G., H.F.B., I.E.

Conflict of Interest: The authors declare that they have no conflict of interest.

Financial Disclosure: The authors declare that this study received no financial support.

\section{References}

[1] Moch H, Humphrey PA, Ulbright TM, Reuter VE. WHO Classification of Tumours of the Urinary System and Male Genital Organs. 4th Edition, Volume 8. Lyon, France: International Agency for Research on Cancer; 2016.

[2] Nagata M, Kurimoto S, Takeuchi T, Ohta N, Minowada S, Kitamura T. Tiny Nodule in the Testicle: Case Report of a Sertoli Cell Tumor. Int J Urol 2004;11:61-2. https://doi.org/10.1111/j.1442-2042.2004.00727.x.

[3] Mostofi FK, Price EB. Tumors of the Male Genital System [Atlas of Tumor Pathology]. 2nd series, fascicle 8. Washington DC: Armed Forces Institute of Pathology; 1973.

[4] Pick L. Ueber Neubildungen am genitale bei Zwittern (nebst beiträ gen zur Lehre von den Adenomen des Hodens und Eierstockes). Archiv für Gynäkologie 1905;76:191-281. https://link.springer.com/article/10.1007/BF01834723.

[5] Stalker AL, Hendry WT. Hyperplasia and Neoplasia of the Sertoli Cell. J Pathol Bacteriol 1952;64:161-8. https://doi.org/10.1002/path.1700640116.

[6] Halley JB. The Growth of Sertoli Cell Tumors: A Possible Index of Differential Gonadotrophin Activity in the Male. J Urol 1963;90:220-9. https://doi.org/10.1016/s0022-5347(17)64394-5.

[7] Hedinger CE, Huber R, Weber E. Frequency of So-called Hypoplastic or Dysgenetic Zones in Scrotal and Otherwise Normal Human Tests. Virchows Arch Pathol Anat Physiol Klin Med 1967;342:165-8. https://doi.org/10.1007/BF00960585.

[8] Roth LM, Czernobilsky B. Macroscopic Sertoli Cell Nodule of the Testis Containing Numerous Spermatogonia. Pathol Res Pract 2016;212:943-5. https://doi.org/10.1016/j.prp.2016.07.006.

[9] Wohlfahrt-Veje C, Main KM, Skakkebaek NE. Testicular Dysgenesis Syndrome: Foetal Origin of Adult Reproductive Problems. Clin Endocrinol (Oxf) 2009;71:459-65. https://doi.org/10.1111/j.1365-2265.2009.03545.x.

[10] Manisha B, Narayani J, Nag BP, Yadav ML. Sertoli Cell Nodule of the Testis: An Incidental Finding. IAIM 2017;4:64-7.

http://oaji.net/articles/2017/1398-1493351876.pdf. 
[11] Ulbright TM, Amin MB, Young RH. Intratubular Large Cell Hyalinizing Sertoli Cell Neoplasia of the Testis: A Report of 8 Cases of a Distinctive Lesion of the Peutz-Jeghers Syndrome. Am J Surg Pathol 2007;31:827-35.

https://doi.org/10.1097/PAS.0b013e3180309e33.
[12] Govender D, Sing Y, Chetty R. Sertoli Cell Nodules in the Undescended Testis: A Histochemical, Immunohistochemical, and Ultrastructural Study of Hyaline Deposits. J Clin Pathol 2004;57:802-6.

https://doi.org/10.1136/jcp.2004.015982. 